[Agr. Biol. Chem., Vol. 34, No. 2, 159 163, 1970]

\title{
Studies on Milk Clotting Enzymes Produced by Basidiomycetes
}

\section{Part I. Screening Tests of Basidiomycetes for the Production of Milk Clotting Enzymes}

\author{
By Masanobu KawaI and Noboru MukaI \\ Kyowa Hakko Kogyo Co., Ltd., Tokyo Research Laboratory, \\ Asahi-machi, Machida, Tokyo \\ Received May 16, 1969
}

\begin{abstract}
In the course of screening tests of Basidiomycete proteolytic enzymes, it was observed that some strains produced milk clotting enzymes with fairly weak proteolytic activitics.

When sucrose-polypeptone and sucrose-corn steep liquor media were used, only 6 strains out of 44 strains tested showed weak milk clotting activities. Cheddar cheese making with culture filtrates of these 6 strains revealed that the culture filtrates of 2 strains, Irpex lacteus Fr. and Fomitopsis pinicola (Fr.) Karst., were able to produce Cheddar cheese of good quality.

On the other hand, when sucrose-distillers solubles media were used, a lot of strains showed high proteolytic activity in addition to high milk clotting activity. The ratio of milk clotting to proteolytic activities (MCA/PA) was assumed to be an important index for the selection of organism, and $F$. pinicola and Coriolus consors (Berk.) Imaz. were selected as the strain with high MCA/PA ratio.

As the investigation on culture conditions of 3 strains mentioned above showed that $F$. pinicola and 1 . lacteus, were richly productive of milk clotting enzymes, the 2 strains except C. consors were used for further studies on cheese making.

Cheddar cheese making with crude enzymes revealed that cheese products produced by the enzyme of $F$. pinicola had a slightly bitter taste after 5 months' ripening but that those produced by the enzyme of $I$. lacteus had good quality.
\end{abstract}

Because of the gradual shortage of the animal rennet prepared from the abomasums of young calves and the increasing demand for cheese products, the interest in rennet substitutes has been greatly increased in recent years. $^{1,21}$

A great number of studies on rennet substitutes have been reported. According to Naudts," there are many milk clotting enzymes prepared from animals, vegetables ${ }^{3 \sim 8}$

1) Ir. M. Naudts, International Dairy Federation, Moscow, I-Doc 51 (1968).

2) H. A. Veringa, Dairy Sci. Abst., 23, 197 (1961).

3) R. Berkowitz-Hundert, J. Leibowitz and J. Ilany-

Feigenbaum, Enzymologia, 27, 332 (1964). and microbes..$^{922}$ The enzymes with a few exceptions thus far reported, however, had

4) R. Berkowitz-Hundert, J. Ilany-Feigenbaum and J. Leibowitz, Enzymologia, 29, 98 (1965).

5) R. Berkowitz-Hundert, ibid., 31, 281 (1966).

6) J. Ilany-Feigenbaum, R. Berkowitz-Hundert and J. Leibowitz, ibid., 31, 274 (1966).

7) M. A. Krishnaswmy, D. S. Johar, V. Subrahmanyan and S. P. Thomas, Food Tech., 15, 482 (1961). 8) K. Ramamurti and D. S. Johar, Naturwiss., 51, 88 (1964).

9) S. M. Barkan, O. Kb. Ramazanova and A. A. Yulius, Dairy Sci. Abst., 27, 152 (1965).

10) T. Kikuchi, J. Food Sci. Tech., 15, Abst. of 15th Meeting (1968).

11) S. G. Knight, Can. J. Microbiol., 12, 420 (1966).

12) N. P. Melachouris and S. L. Tuckey, J. Dairy Sci., 50, 943 (1967).

13) J. L. Sardinas, Appl. Microbiol., 16, 248 (1968). 
high proteolytic activities in addition to milk clotting activities, so that the cheese produced by those enzymes had a soft curd texture or had an off-flavor, especially a bitter taste.

Only two enzymes, pepsin ${ }^{1,2}$ and the enzyme produced from Mucor pusillus, ${ }^{15-221}$ have so far been regarded as the promising rennet substitutes.

In the course of studies on proteolytic enzymes from Basidiomycetes, it was observed that some strains produced milk clotting enzymes with fairly weak proteolytic activities. The present paper deals with the screening of Basidiomycetes for the production of milk clotting enzymes.

\section{MATERIALS AND METHODS}

Basidiomycete strains tested and the assay methods for proteolytic activity. Proteolytic activity (PA) was expressed in optical density at $660 \mathrm{~m} \mu$ per one $\mathrm{ml}$ of culture filtrates. Assay techniques and the strains used were previously described.231

Compositions of culture media. A medium composed of $5 \%$ of sucrose, $0.3 \%$ of yeast extract, $0.1 \%$ of $\mathrm{KH}_{2} \mathrm{PO}_{4}$, and $0.05 \%$ of $\mathrm{MgSO}_{4} \cdot 7 \mathrm{H}_{2} \mathrm{O}$ was used as a basal one, and to this medium $0.5 \%$ of polypeptone, $2 \%$ of corn steep liquor (CSL), or $3 \%$ of distillers solubles (SVP) was added as a nitrogen source.

Cultivating methods of Basidiomycete strains are

14) R. A. Srinivasan, M. K. K. Iyengar, I. J. Babbar, S. C. Chakravorty, A. T. Dudani and K. K. Iya, Appl. Microbiol., 12, 475 (1964).

15) K. Arima, S. Iwasaki and G. Tamura, Agr. Biol. Chem., 31, 540 (1967).

16) S. Iwasaki, G. Tamura and K. Arima, ibid., 31, $546,1421,1427$ (1967).

17) J. Yu, S. Iwasaki and K. Arima, ibid., 32, 1048, 1051 (1968).

18) G. A. Somkuti and F. J. Babel, Appl. Microbiol., 15, 1309 (1967).

19) G. A. Somkuti and F. J. Babel, J. Bact., 95, 1407,1415 (1968).

20) G. H. Richardson, J. H. Nelson, R. E. Lubnow and R. L. Schwarbery, J. Dairy Sci., 50, 1066 (1967)

21) T. Tsugo, U. Yoshino, K. Taniguchi, A. Ozawa, A. Miki, S. Iwasaki and K. Arima, Jap. J. Zootech. Sci., 35, 221, 229 (1964).

22) M.E. Schulz, E. Voss, H. Sell und G. Mrowetz, Milchwiss., 22, 139 (1967). referred to the previous paper. ${ }^{23}$

An assay method for milk clotting activity. Twelve per cent solution of milk powder fortified with $\mathrm{M} / 1000$ $\mathrm{CaCl}_{2} \cdot 2 \mathrm{H}_{2} \mathrm{O}$ was used as a substrate.

For assay of the enzyme activity $10 \mathrm{ml}$ of the substrate solution, whose $\mathrm{pH}$ value was adjusted with in $\mathrm{HCl}$ exactly to 6.2 , was added to $1 \mathrm{ml}$ of enzyme solution of a suitable dilution at $35^{\circ} \mathrm{C}$.

The time necessary for the formation of curd fragments was measured with a stop watch. Milk clotting activity (MCA) was defined as follows.

$$
\mathrm{MCA}=\frac{2400}{t(\mathrm{sec})} \times \text { dilution coefficient }
$$

$t$ : Time necessary for the curd fragment formation.

Manufacture of Cheddar cheese. ${ }^{24,251}$ To fresh milk pasteurized at $62^{\circ} \mathrm{C}$ for $30 \mathrm{~min}$ and cooled at $30^{\circ} \mathrm{C}$ $2 \%$ of starter was added, and immediately after titratable acidity of milk was adjusted to $0.2 \%$ as lactic acid by the addition of $1 \mathrm{~N} \mathrm{HCl}$, enzymes or culture filtrates were added to the milk.

After 30 min, curd of milk was cut and gradually cooked from 30 to $37^{\circ} \mathrm{C}$. Whey was removed when acidity of whey became $0.035 \%$ more than that measured immediately after the cutting. When acidity of whey draining from curd block during cheddaring became $0.45 \%$, the curd was milled and blended with $2 \%$ of $\mathrm{NaCl}$. After that the curd was hooped and pressed.

After $24 \mathrm{hr}$, the pressed cheese was coated with paraffin and stored in a refrigerator at $10 \sim 15^{\circ} \mathrm{C}$.

\section{RESULTS}

\section{Screening tests in the sucrcse-polypeptone or the sucrose-CSL media}

Results of screening tests when polypeptone or CSL was used as a nitrogen source are shown in Table I.

When organisms were cultivated in the sucrose-polypeptone medium, only 3 strains showed weak milk clotting activities, and in the sucrose-CSL medium 6 strains had also

23) M. Kawai and Y. Otsuka, Trans. Mycol. Soc. Japan, 10(1), 29 (1969).

24) "Shokuhin Kako Ho," ed. by K. Osaki, Asakura Co., Tokyo, 1964, p. 411.

25) T. Yamamoto, K. Takahashi and M. Yoshino, Bull. National Institute Agr. Sci., Series G, 15, 69 (1958). 
Table I. A Result of Screening Tests For the Production of Milk Clotring Enzymes IN THE SUCROSE-POLYPEPTONE AND THE SUCROSE-CSL MEDIUM

\begin{tabular}{|c|c|c|}
\hline & & MCA \\
\hline strain & Species names & $\begin{array}{c}\text { Polypeptone } \\
\text { medium }\end{array}$ \\
\hline
\end{tabular}

\begin{tabular}{|c|c|c|c|}
\hline 1 & $\begin{array}{l}\text { Coprinus macrorhizus } f \text {. } \\
\text { microsporus }\end{array}$ & 0 & 0 \\
\hline 2 & " " " & 0 & 0 \\
\hline 3 & $" \prime \prime$ & 0 & 0 \\
\hline 4 & Coprinus micaceus & 0 & 0 \\
\hline 5 & $"$ radians & 0 & 0 \\
\hline 6 & $n \quad \|$ & 0 & 0 \\
\hline 7 & Coprinus sp. & 0 & 0 \\
\hline 8 & Naematoloma fasciculare & 0 & 0 \\
\hline 9 & Oudemansiella radicata & 0 & 0 \\
\hline 10 & Agaricus bisporus & 0 & 0 \\
\hline 11 & Clavaria mucida & 0 & 0 \\
\hline 12 & Flammulina velutipes & 0 & 0 \\
\hline 13 & Lentinus edodes & 0 & 0 \\
\hline 14 & " " & 0 & 0 \\
\hline 15 & Pholiota nameko & 0 & 0 \\
\hline 16 & Pleurotus ostreatus & 0 & 0 \\
\hline 17 & " " " & 0 & 0 \\
\hline 18 & Armillaria mellea & 0 & 0 \\
\hline 19 & Coriolus consors & 0 & 0 \\
\hline 20 & " $" \prime$ & 0 & 0 \\
\hline 21 & " hirsutus & 0 & 0.2 \\
\hline 22 & "versicolor & 0 & 0.2 \\
\hline 23 & Daedaleopsis styracina & 0.2 & 0.3 \\
\hline 24 & " & 0 & 0 \\
\hline 25 & Elfuingia applanata & 0 & 0 \\
\hline 26 & Fomes fomentarius & 0 & 0 \\
\hline 27 & Fomitopsis annosa & 0 & 0 \\
\hline 28 & " castanea & 0 & 0 \\
\hline 29 & insularis & 0 & 0 \\
\hline 30 & " & 0 & 0 \\
\hline 31 & officinalis & 0 & 0 \\
\hline 32 & pinicola & 0 & 0.5 \\
\hline 33 & " cytisina & 0 & 0 \\
\hline 34 & Fuscoporia obliqua & 0 & 0 \\
\hline 35 & Irpex lacteus & 0.5 & 1.4 \\
\hline 36 & Lampteromyces japonicus & 0 & 0 \\
\hline 37 & Lenzites betulina & 0.5 & 0.5 \\
\hline 38 & Gloeophyllum saepiarium & 0 & 0 \\
\hline 39 & " " & 0 & 0 \\
\hline 40 & Panellus stipticus & 0 & 0 \\
\hline 41 & Phaeolus schweinitzii & 0 & 0 \\
\hline 42 & Schizophyllum commune & 0 & 0 \\
\hline 43 & Stereum hirsutus & 0 & 0 \\
\hline 44 & Trametes sanguinea & 0 & 0 \\
\hline
\end{tabular}

MCA: Milk clotting activity.
TABLe II. A Result of SCReEning Tests for the Production of Milk Clotting Enzymes IN THE SUCROSE-SVP MEDIUM

Nos. of SVP medium ( $\mathrm{pH} 4.5)$ SVP medium ( $\mathrm{pH} 5.5)$ strains MCA PA MCA/PA MCA PA MCA/PA

\begin{tabular}{|c|c|c|c|c|c|c|}
\hline 1 & 4.4 & 0.286 & 15.4 & 6.8 & 0.740 & 9.2 \\
\hline 2 & 4.8 & 0.468 & 10.2 & & & \\
\hline 3 & 2.9 & $0.44 \mathrm{I}$ & 6.6 & 7.3 & 1.340 & 5.4 \\
\hline 4 & 0 & & & 0 & & \\
\hline 5 & 0 & & & 0 & & \\
\hline 6 & 0 & & & 0 & & \\
\hline 7 & 0 & & & 0 & & \\
\hline 8 & 0 & & & 0 & & \\
\hline 9 & 0 & & & 0 & & \\
\hline 10 & 0 & & & 0 & & \\
\hline 11 & 0 & & & 0 & & \\
\hline 12 & 2.1 & 0.522 & 4.0 & 2.2 & 0.885 & 2.5 \\
\hline 13 & 0 & & & 0 & & \\
\hline 14 & 0 & & & 0 & & \\
\hline 15 & 0 & & & 0 & & \\
\hline 16 & 2.0 & 0.412 & 4.9 & 0 & & \\
\hline 17 & 1.4 & 0.595 & 2.4 & 2.0 & 0.365 & 5.5 \\
\hline 18 & 0 & & & 1.0 & 0.150 & 6.7 \\
\hline 19 & 1.5 & 0.145 & 10.3 & 13.0 & 0.950 & 13.7 \\
\hline 20 & 4.5 & 0.079 & 57.0 & 3.3 & 0.025 & 132.0 \\
\hline 21 & 4.4 & 0.310 & 14.0 & 25.3 & 1.055 & 24.0 \\
\hline 22 & 13.7 & 0.655 & 20.9 & 7.8 & 0.285 & 27.4 \\
\hline 23 & 12.6 & 0.655 & 19.2 & 15.5 & 1.150 & 13.5 \\
\hline 24 & 0 & & & 0 & & \\
\hline 25 & 3.1 & 0.475 & 6.5 & 3.2 & 0.120 & 26.7 \\
\hline 26 & 16.0 & 0.455 & 35.2 & 2.0 & 0.355 & 5.6 \\
\hline 27 & 1.7 & 0.045 & 37.8 & 5.1 & 0.260 & 19.6 \\
\hline 28 & 7.8 & 0.745 & 10.5 & 7.8 & 0.850 & 9.2 \\
\hline 29 & 0 & & & 0 & & \\
\hline 30 & 0 & & & 0 & & \\
\hline 31 & 0 & & & 0 & & \\
\hline 32 & 7.8 & 0.165 & 47.2 & 10.9 & 0.415 & 26.3 \\
\hline 33 & 4.6 & 1.830 & 2.5 & 7.8 & 1.515 & 5.1 \\
\hline 34 & 0 & & & 0 & & \\
\hline 35 & 20.0 & 1.305 & 15.3 & 13.3 & 1.180 & 11.3 \\
\hline 36 & 1.8 & 0.270 & 6.7 & 0 & & \\
\hline 37 & 12.6 & 0.705 & 17.9 & 6.4 & 1.010 & 6.3 \\
\hline 38 & 4.4 & 0.335 & I 3.1 & 2.0 & 0.350 & 5.7 \\
\hline 39 & 0 & & & 0 & & \\
\hline 40 & 4.5 & 0.740 & 6.4 & 0 & & \\
\hline 41 & 0 & & & 0 & & \\
\hline 42 & 2.5 & 0.122 & 20.5 & 2.9 & 0.455 & 6.5 \\
\hline 43 & 0 & & & 0 & & \\
\hline 44 & 43.6 & 1.545 & 28.2 & 16.0 & 1.240 & 12.9 \\
\hline
\end{tabular}

MCA: Milk clotting activity, and PA: Proteolytic activity at $\mathrm{pH} 6$. 
weak activities, overlapping 3 strains mentioned above.

In both media the growth of strains tested was poor and mycelia of almost all strains formed large pellets. Probably because of poor growth in both media, only a few strains had detectable milk clotting activities.

Cheddar cheese making on a small laboratory scale ${ }^{24)}$ using the culture filtrates of those six strains revealed that normal cheese textures were made by the culture filtrates of Fomitopsis pinicola (Fr.) Karst. and Irpex lacteus Fr., but that soft curds were formed using those of other four strains.

After ripening of these cheese products at $10 \sim 15^{\circ} \mathrm{C}$ for 6 months, the ones produced by the culture filtrales of $F$. pinicola and I. lacteus had no off-flavor, but other products had an irritative bitter taste.

\section{Screening tests in the sucrose-SVP medium}

In the sucrose-SVP medium the growth of many strains was better than in the sucrosepolypeptone and the sucrose-CSL media, and almost all strains formed very small pellets or pulpy mycelia.

In this medium a lot of strains became to be able to clot milk (Table II), but at the same time proteolytic activities became also high.

As a rennet substitute it is necessary that the enzyme has not only high milk clotting activity, but also low proteolytic activity. Therefore, the ratios of milk clotting activity

Table III. Some Comparisons of Characteristics BETWEEN A TRADITIONAL ANIMAL RENNET AND Microbial Rennets on the Market

\begin{tabular}{ccccc}
\hline & & $\mathrm{MCA} / \mathrm{mg} \mathrm{PA} / \mathrm{mg}$ & $\mathrm{MCA} / \mathrm{PA}$ \\
\hline $\begin{array}{c}\text { Animal } \\
\text { rennet }\end{array}$ & $\begin{array}{c}\text { Hansen's } \\
\text { powder }\end{array}$ & 15.0 & 0.090 & 167.0 \\
$\begin{array}{c}\text { Microbial } \\
\text { rennet }\end{array}$ & $\begin{array}{c}\text { Pfizer's rennet } \\
\text { Meito's rennet }\end{array}$ & $\begin{array}{l}45.0 \\
16.0\end{array}$ & 1.390 & 32.4 \\
& Me.322 & 49.7 \\
\hline
\end{tabular}

MCA: Milk clotting activity and PA: Proteolytic activity indicated in optical density at $660 \mathrm{~m} \mu$. to proteolytic activity (MCA/PA) of three rennets on the market, i.e. Hansen's calf rennet, Mucor pusillus rennet (Meito's rennet) and Endothia parasitica rennet (Pfizer's rennet), were measured and adopted as the index of screening tests (Table III).

As a result, two strains, Coriolus consors (Berk.) Imaz. and $F$. pinicola, were selected owing to their high MCA/PA ratio.

As the study on culture conditions of 3 strains mentioned above showed that $F$. pinicola and $I$. lacteus were richly productive of milk clotting enzymes the 2 strains except C. consors were used for further studies on cheese making.

Manufacture of Cheddar cheese revealed that cheese products produced by the enzyme of $F$. pinicola had a slightly bitter taste after 5 months' ripening but that those produced by the enzyme of $I$. lacteus had good quality.

\section{DISCUSSION}

Since almost all proteolytic enzymes clot milk, a great variety of proteolytic enzymes obtained from various sources were tested as animal rennet substitutes. Unfortunately, however, their strong proteolytic activity that caused curd peptonization or off-flavor, especially a bitter taste, prevented them from being used in cheese manufacture.

Attempts to separate milk clotting activity from proteolytic activity have so far been unsuccessful. ${ }^{14 \prime}$ Milk clotting activity seems to be invariably accompanied by proteolytic activity. This is why the ratio of milk clotting to proteolytic activity was referred to as the index for screening tests. If it is taken into consideration that in cheese manufacture $\mathrm{pH}$ values of fresh milk, when rennet preparations are added, is $6.2 \sim 6.3,{ }^{25)} \mathrm{MCA} / \mathrm{PA}$ ratio at $\mathrm{pH} 6$ will be the important index of organisms.

However, it is hard to decide, until the cheese products are actually produced and tasted, whether or not the products with a 
good flavor are able to be produced by the rennet substitutes in question.

Judging from the se points, $I$. lacteus, by the enzyme of which good quality of Cheddar cheese could be produced, is chosen a promising strain.
Acknowledgements. The authors wish to express their sincere thanks to Dr. G. Tikuma and Dr. M. Yoshino, National Institute of Animal Industry, for their valuable advices and excellent cheese making. They also wish to thank Miss F. Matsumoto and Mr. Y. Ogawa for their assistance throughout this work. 